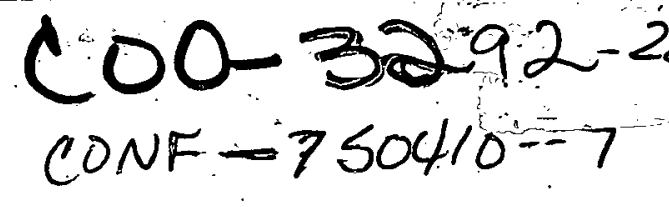

SPATIAL AND TENPORAL VARTATIONS IN THE INTERSTITIAL IATER CHEMISTRY. OF CHESAPEAKE BAY SEDINENTS

Gerald Natisoff, Owen P. Bricker III, George R. Holdren Jr., and Peter Kaerk

Department of Earth and Planetary Sciences, The Johns Hopkins. University, Baltimore, Maryland 21218

The calculation of chemical mass balance relations in an estuarine environment requires a careful evaluation of the material fluxes within the sediment and across the sediment-water. interface. The rapid response of the estuarine environment to variations in temperature, salinity and sedinent deposition rates makes this type of assessment very difficult. One approach is to examine the integrated results of these effects in terms of the spatial and temporal variability of the concentrations of dissolved species in the sedinent. Spatial variations define the limits which may be placed upon the instantaneous conccntrations of chenical species as a function of location. Temporal variations interpreted within the framework of the spatial limits may be used to assess the long-term effects of temperature, salinity and sediment deposition rates, thus enabling the more accurate calculations of chemical fluxes.

\title{
Nature of the Study
}

The validity of a temporal study hinges lipon the ability to accurately relocate the same sampling sites throughout the study period. A realistic evaluation of the navigational capabilities during the period of the study indicates that relocation within a circle of $500^{\prime}$ diameter was possible in open waters. Where stations were close to buoys or other fixed points, accuracy of relocation was substantially improved.

Temporal data were collected at station $856-\mathrm{C}$ and $856-\mathrm{E}$ for the period June, 1971 through September, 1973. Nost of the data were collected prior to the observations of Bray et al. (2) on the effects of sample oxidation and consequently, the data are not reliable for any metals, phosphate or Eh. The chloride, silicate, sulfate and ammonia concentrations as vell as carbonate alkalinity are unaffected by oxidation during squeezing of the sample and these data are preserted below.

A spatial study was conducted in Chesapeake Bay on April 1416, 1974 to evaluate the variability in inierstitial water 


\section{DISCLAIMER}

This report was prepared as an account of work sponsored by an agency of the United States Government. Neither the United States Government nor any agency Thereof, nor any of their employees, makes any warranty, express or implied, or assumes any legal liability or responsibility for the accuracy, completeness, or usefulness of any information, apparatus, product, or process disclosed, or represents that its use would not infringe privately owned rights. Reference herein to any specific commercial product, process, or service by trade name, trademark, manufacturer, or otherwise does not necessarily constitute or imply its endorsement, recommendation, or favoring by the United States Government or any agency thereof. The views and opinions of authors expressed herein do not necessarily state or reflect those of the United States Government or any agency thereof. 


\section{DISCLAIMER}

Portions of this document may be illegible in electronic image products. Images are produced from the best available original document. 
chemistry over a small spatial range. The mid-bay region with a salinity approximating half that of sed water was chosen for this study. Three stations forming a transect across the bay at $38^{\circ}$ $53^{\prime} \mathrm{N}$ (Station 853) and a fourth station at $39^{\circ} 03^{\prime} 52^{\prime \prime} \mathrm{N}, 76^{\circ} 19^{\prime} 20^{\prime \prime} \mathrm{W}$ (Station 904i) were sampled (Fig. 1).

$\angle 5$ Either four or five sets of gravity cores were obtained in a

$4 \dot{4}$ " "T"-shaped pattern at each station, with approximately 100'

43 spacing between each coring location. Two cores were taken at

42 each sampling site, one for physical description and one for

42. chenical analysis. The core used for chemical analysis was

$\therefore$ extruced and squeezed at room temperature with a Reeburgh-type

39. squeezer (1) in a nitrogen atmosphere to prevent oxidation of

33. metals (2). Measurements of $\mathrm{pH}, \mathrm{pS}^{=}$and Eh were made by elec-

37 .trode methods in a closed cell in the nitrogen-filled glove box and samples for iron, phosphate and other oxygen-sensitive species were prepared in the box.

Analytical Techniques

In general, ten interstitial water samples were squeezed from sediment sections of each of the cores. The first five sample sections were two centimeters in thickness, and together comprised the top ten centimeters of the core. Three centimeter sections were obtained at about $15-18 \mathrm{~cm}$, and $25-28 \mathrm{~cm}$. The remaining sample sections were $5 \mathrm{~cm}$ each, and their locations were dependent upon the length of the core. All data are plotted as the midpoint of each section. Bottom water values were determined from the water which was trapped in the core tube above the top of the sediment.

Since only 20-50 $\mathrm{ml}$ of sample are obtained from each squeezed section, analytical methods which require only small aliquots of sample must be used. Some of the analytical methods have been taken directly from the literature, while others are modified versions of existing methods. In all cases, the analytical methods were tested for accuracy, precision, and interferences. When found necessary appropriate corrections were made. Table I sumnarizes the analytical methods which we used.

Results and Discussion each of the four stations sampled in the spatial variation study. We show here the data for station $853-C$ which is representative of the quality for all the stations. Also included are additional data from a shallow water station, 853-G. The best arreement between each of the chemical species and between the physical core descriptions is found in the data from station 853-E (not shown). Although we present only a part of our rotal results in this communication, the estimated limits of spatial variability have been determined taking into account all four stations. 


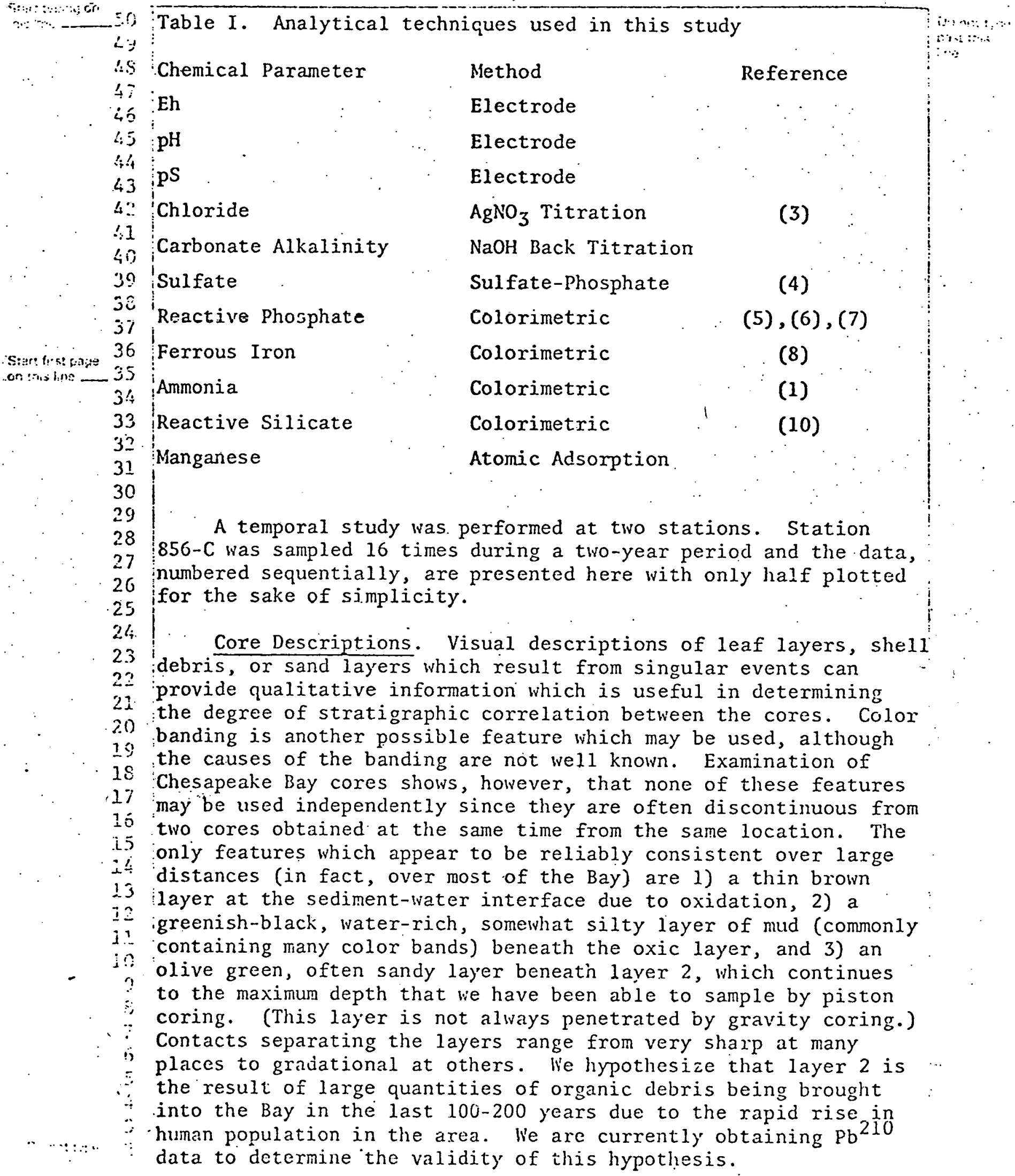

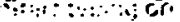
(1) - 50 $2 y$ $\therefore S$

47

46

45

4.4

43

$4:-$

$\therefore 1$

40

39

उहै

37

Stare fi-st barase on: tistins 35

34

33

32

31

30

29

28

27

26

25

24.

23

22

$2 i$

20

19

Is

17

15

i.5

it

13

I2

i..

is

$?$

$\because$

$\because$

$\therefore$

$\overline{-}$

$\because$

$\because$

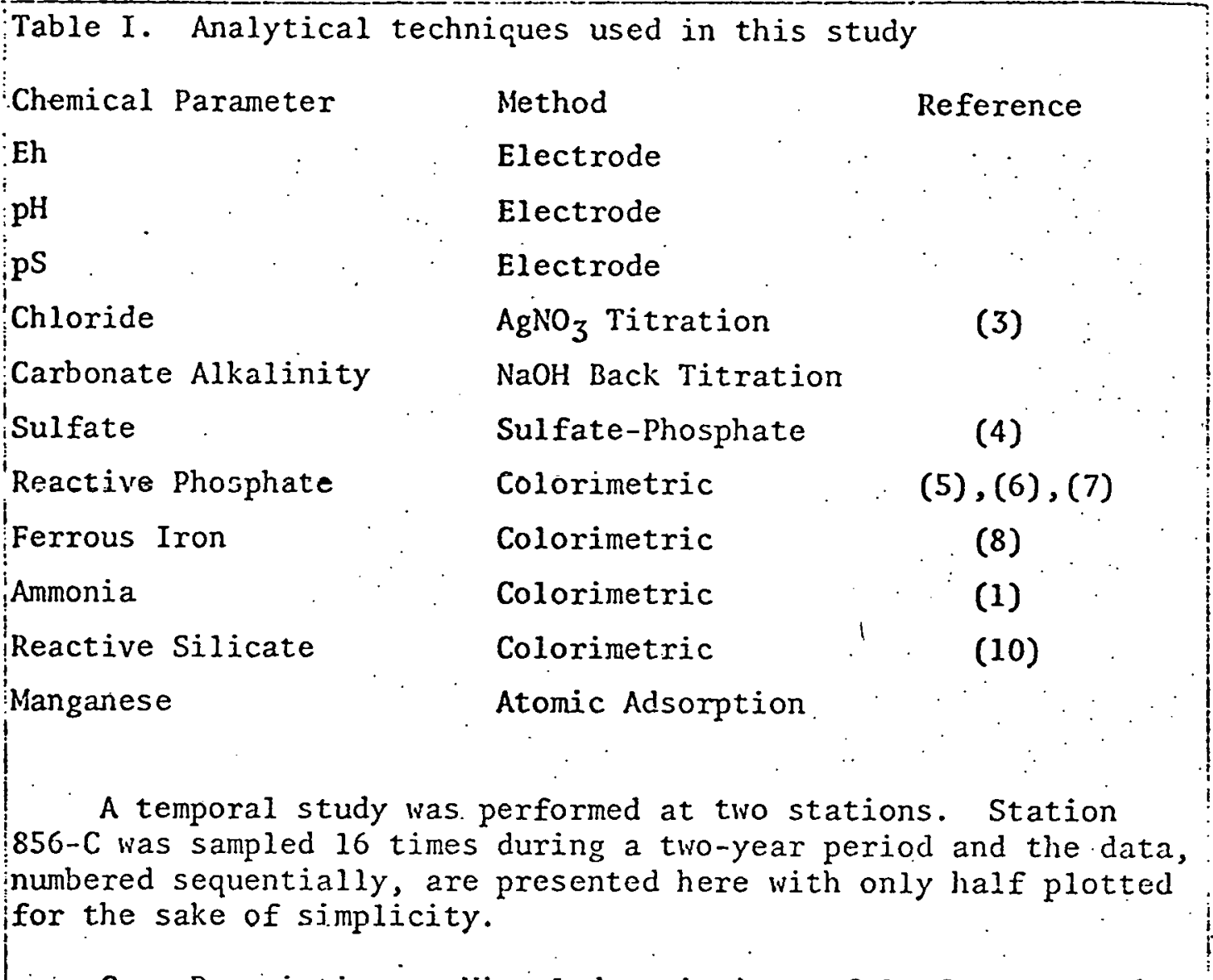

Core Descriptions. Visual descriptions of leaf layers, shell debris, or sand layers which result from singular events can provide qualitative information which is useful in determining the degree of stratigraphic correlation between the cores. Color banding is another possible feature which may be used, although the causes of the banding are not well known. Examination of Chesapeake Bay cores shows, however, that none of these features may be used independently since they are often discontinuous from two cores obtained at the same time from the same location. The only features which appear to be reliably consistent over large distances (in fact, over most of the Bay) are 1) a thin brown layer at the sediment-water interface due to oxidation, 2) a greenish-black, water-rich, somewhat silty layer of mud (commonly containing many color bands) beneath the oxic layer, and 3) an olive green, often sandy layer beneath layex 2, which continues to the maximum depth that we have been able to sample by piston coring. (This layer is not always penetrated by gravity coring.) Contacts separating the layers range from very sharp at many places to gradational at others. We hypothesize that layer 2 is the result of large quantities of organic debris being brought into the Bay in the last 100-200 years due to the rapid rise in human population in the area. We are currently obtaining $\mathrm{Pb}^{210}$ data to determine the validity of this hypothesis.

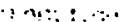
:1, : : : : $\because \cdots$ 

ships (see Figure 2). They are particularly abundant in the sediment just south of Baltinore Harbor. Core descriptions from five cores at station $853-E$ show that a single "clinker" layer exists in each core at the following depths: $43 \mathrm{~cm}, 43 \mathrm{~cm}, 47 \mathrm{~cm}$, $: 43 \mathrm{~cm}, 45 \mathrm{~cm}$. In all of the cores these clinkers were found at, or just above the contact between layers 2 and 3 . This spatial agreement is also offered as evidence in support of the above hypothesis.

41

40

Chloride.

Chloride may be treated as a conservative tracer during mixing of natural waters. When investigating the exchange of water across the sediment-water interface, it is thereforc important to examine lhe chloride ion distribution.

In Figure 3, spatial data for chloride concentrations at station 853-C are presented. It is quite obvious that there is excellent agreement among the five cores obtained at this deep water station. The agreement is not nearly as good at the shallow water station 853-G (Figure 4). Extremely low chloride values at depth suggest dilution by discharge from a fresh-water aquifer into the Bay environment. Comparison of chloride concentrations between these two stations, both at the sediment surface and at depth in the sediment, reveals that the values are much higher at the deep water station. This reflects the fact that the salt-water wedge travels farther up the bay in the main channel of the estuary than it does along the shallower sides. Data for interstitial chloride values which are uncontaminated by ground-water discharge appear to be good to $\pm 1.5 \%$ and reflect the mean salinity of the local environment.

Temporal data for chloride is presented in Figure 5. Near the sediment surface there is considerable systematic variation with time. Late spring values are lowest due to the high volume of fresh water discharged into the Bay, while late fall values are the highest reflecting decreased river discharge and increased evapotranspiration. It appears that the upper $20 \mathrm{~cm}$ or so of the sediment responds rapidly to salinity changes at the sedimentwater interface, while the sediment below this reflects a longerterm average of the salinity in the overlying water. This is further supported by examining cores 9, 11, 12, and 13. Core 10, obtained May 25, 1972 (not shown), plots between cores 9 and 11, and reflects a wet spring. Core 11 was obtaincd 5 days after Hurricane Agnes passed through the Chesapeake Bay area, and the upper part of the core is even more depleted in chloride than usual for cores collected during a normal spring. A month later (core 12), chloride is strikingly absent in the upper part of the core. Two months after Agnes, the uppermost part of the core had responded to an increase in chloride resulting from the reestablishment of the salinity wedge, although the erfects of the storm are still apparent (core 13 ). Subsequent data (not 
presented) show complete recovery from the effects of Hurricane

$\therefore$ Agnes. This sequence of data indicates the rapiclity of response

$\therefore$ of the upper part of the sediment column to fluctuations in the

$\therefore i$ salinity of the overlying water. Further discussion and a nathe

46 matical model for the chloride distribution are presented in the

45 next paper of this symposium by Holdren, et al. (11).

$4 . ;$

Silicate. Interstitial silicate concentrations are typi-

41 values. Diaton dissolution is

4i) $(13,14)$ and clay mineralion is an important source of silica

39 Silica (12). Both diatom distions can either release or take up

33 are complicated functions of

37 sediment composition, and

35 simple explanation of and particle size (15 and 16), so that a

18

17

16

ij

is

12

12

Figure 6 shows the spatial data for silica at station 853-C. The data for this station and the three other stations not shown suggest that silica values are good to $\pm 10 \%$. Examining figure 7 , one can see that the data varies by as much as $450 \%$. Note that data obtained during the winter months exhibit low concentrations of dissolved silica, and increase with depth, whereas summer data show very high values, and decrease with depth. This seasonal variation suggests a strong temperature control on the dissolved silica concentrations. This effect must be greater than the error introduced by squeezing at room temperature (17), since the effect of squeezing at one temperature would be to minimize the spread of the data. Squeezing samples at in situ temperatures would be enormously cumbersome, since strong temperature gradients exist within the core itself (18). We are currently working on a mathematical model which will describe this seasonal variation in terms of temperature fluctuations.

Sulfate. Chesapeake Bay sediments are rich in organic material, and its decomposition plays a major role in the chemistry of the interstitial waters. The anaerobic decomposition of organic matter by sulfate reducing bacteria may be written as (19 and 7)

$$
\begin{aligned}
& \left(\mathrm{CH}_{2} \mathrm{O}_{106}\left(\mathrm{NH}_{3}\right)_{16} \mathrm{H}_{3} \mathrm{PO}_{4}+53 \mathrm{SO}_{4}=\right. \\
& 106 \mathrm{HCO}_{3}^{-}+53 \mathrm{HS}^{-}+16 \mathrm{NH}_{4}^{+}+\mathrm{HPO}_{4}=+39 \mathrm{H}^{+}
\end{aligned}
$$

Thus, an interdependency exists among sulfate, carbonate alkalinity, ammonia, phosphate, $\mathrm{pH}$, and $\mathrm{Eh}$. In addition, the presence of large quantities of iron and manganese in the sediment results in other dependencies due to precipitation of iron and manganese sulfides, phosphates, and carbonates. The system is still affected, however, by the same physical processes that control 


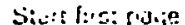

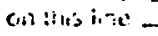

sediment-water interface will, therefore, have an important

t. influence on the sulfate distribution. Temperature fluctuations

$\therefore ;$ affect the rate of organic decomposition and, therefore, the rate

$\therefore 5$ of reduction of sulfate and production of the species in equation

$\therefore 5 i 1$. One would thus expect a rough seasonal correlation among

$4 ;$ these species, but as an added complexity the composition of the

$\therefore j$ interstitial waters may also be constrained by mineral equilibrium

42 reactions.

$\therefore 1$ Although the spatial data for sulfate is unavailable, it

40) seens reasonable that its reproducibility should be good to at

$3 \%$ least $\pm 10 \%$. Temporal data is presented in Figure 8 . It is

is quite clear that the temporal variation for sulfate far exceeds

37 these estimated spatial limits. This variation shows a seasonal

36 trend. During the warmer months when biological processes are 35 most active, almost all of the sulfate is reduced to sulfide, but during the colder months when these processes slow down, not all of the sulfate that has diffused into the sediment is reduced. The effect of Hurricane Agnes can be seen by examining core 12. Sulfate has been substantially reduced in the upper $15-20 \mathrm{~cm}$ of the core. This is in agreement with chloride data. A month later, essentially all of this sulfate is gone.

Carbonate Alkalinity. At the pH of interstitial waters, the primary component of the carbonate alkalinity is the bicarbonate ion. It is pronluced not only from the oxidation of organic matter by sulfate reducing bacteria as described by equation (1), but also from any "reverse weathering" reactions (20) which might be taking place. If reverse weathering is taking place, its effect on the garbonate alkalinity is probably quite small with respect to bacterial activity. If the alkalinity is produced primarily by bacterially mediated oxidation of organic matter by sulfate, an inverse relationship should exist between sulfate and carbonate (21). Troup (22) and Bray (7) have shown that such a relationship exists for these species in the Chesapeake Bay. Figures 9 and 10 give the spatial data for $853-C$ and $853-G$, respectively. The data appear to be better than $\pm 10 \%$. The shallow-water station exhibits considerably more variation and lower values than the deeper-water station. Comparison of the carbonate alkalinity data with the chloride data for station 853-G suggests that the variation in the carbonate alkalinity reflects a variation in chloride, and hence, a variation in the anount of sulfate available for organic decomposition. Similarly, the magnitude of the carbonate alkalinity at stations $853-G$ and 853-C reflects the chloride concontration at the two stations. Thus, by equation (1), the same effects should be seen in the ammonia and phosphate profiles at the two stations. Exallination of Figures $3 \& 4,9 \& 10,12 \& 13$, and $15 \xi_{\mathrm{t}} 16$ for these effects 
,i: $\overline{\mathrm{i}} \cdots \cdot \because \cdots$

The temporal data in Figure 11 shows greater variation than can be attributed to sampling location. The rough seasonal correlation observed in the sulfate values is less well displayed by the carbonate alkalinity. In addition, the mirror image relationship between sulfate and carbonate alkaiinity which exists for a single core is missing when the temporal data are compared as a group (see Figures 8 and 11).

Ammonia. Ammonia is supplied to the interstitial waters by the decomposition of organic matter. Consequently, it should vary inversely with sulfate and directly with carbonate alkalinity. Spatially, ammonia values appear to be reproducible to $\pm 15 \%$ as seen in Figures 12 and 13 . As predicted, the shallowwater station exhibits a lower ammonia value and greater variation.than the deeper-water station. Temporally, ammonia behaves very much like carbonate alkalinity as would be predicted from equation (1) (compare Figures 11 and 14). Like carbonate alkalinity, ammonia also exhibits an excellent inverse correlation with sulfate on a core by core basis, but the correlation is poor when the two sets of temporal. data are compared as groups.

phosphate. Interstitial phosphate is derived primarily from the oxidation of organic matter, although unlike carbonate alkalinity and ammonia, its concentration is dependent not only upon the extent of oxidation of organic matter, but also upon an equilibirum with vivianite $\left(\mathrm{Fe}_{3}\left(\mathrm{PO}_{4}\right)_{2} \cdot \mathrm{SH}_{2} \mathrm{O}\right)$ (2). Therefore, to explain the phosphate profiles, one must look for superimposed inverse relations with both sulfate and ixon. In addition, it has been shown (2) that both iron and phosphate values are substantially lower in pore waters which were not protected against oxjdation during squeezing than in those which were. Since the majority of the temporal data were collected prior to the developnent of oxidation protection procedures, this iron and phosphate data is suspect and is not presented. Figures 15 and 16 give the results of the spatial study. There is wide variation of spatial agreement for each of the four sampling stations, probably as a result of local equilibriam with vivianite. In agreeinent with the theory that the major source of phosphate is from the oxidation of organic matter, station $853-G$ is considerably lower and exhibits greater variation than station 853-C. The profiles differ from those of carbonate alkalinity and ammonia in that they often decrease with depth. It can be seen in Figure 18 that this is due to an inverse response to iron, implying that phosphate is controlled by an equilibrium with vivianite.

pH. Hydrogen ion activity is predominantly regulated by the bacterial destruction of organic material, with perhaps a minor contribution fron "inverse weathering" reactions and from reduction of iron and manganese hydroxides. Thus, a slight 
decrease in $\mathrm{pH}$ with depth might be expected. Figure 17 shows

$\therefore:$ some of the results of the spatial study. The pil values are

$\therefore$ good to approximately $\pm .2 \mathrm{pH}$ units, with a mean $\mathrm{pH}$ of about

$\therefore ;$ 7.4. The temporal data are incomplete, and therefore not pre-

$\because 5$ sented, but they show no systematic variations, all having

$\because$ values of approximately $7.4 \pm .4$

$\therefore 4$

Eh. The platinum ion electrode potentials are interesting even though the specific reactions taking place at the electrode surface cannot be determined. The redox potential (platinum electrode potential) drops dramatically from about +100 millivolts to 0 or to negative values in the first few centimeters of the sediment, and usually remains relatively constant below $20 \mathrm{~cm}$. Aside from this similar behavior, the profiles from all four stations are very different in shape. It is possible that this is a result of a variation in the intensity of reduction of sulfate. The reason that the oxidation-reduction potential appears to stabilize at the value it does is not yet understood. Values of the potential appear to be reproducible within about \pm 20 millivolts, as seen in Figure 18. Troup (22) has demonstrated that the absolute value of Eh is unimportant in the reduction of ferric oxides and hydroxides to the more soluble ferrous ion as long as the $\mathrm{Eh}$ is no greater than about $0 \mathrm{mv}$. Holdren (23) has shown that this is also true for manganese. Thus, it can be seen that except for the very top of the core, the sediment is anoxic, and hence, iron and manganese species are mobile. A slight increase in the oxidation potential with depth may be due to a subsequent depletion of sulfide by the precipitation of iron sulfides (24). Obviously, any sample to be used for the measurement of the redox potential must be protected against oxidation by air during sampling. Because Eh data collected before 1973 are not réliable, temporal data for Eh are not given.

Iron and Manganese. Weathering processes produce fine grained iron and manganese oxides and hydroxides which are brought into the Bay as colloids or as adsorbed coatings on detrital particles. Because of reducing conditions beneath the sediment-water interface, the metals are reduced to lower oxidation states and become more soluble. Sedinent sampling procedures that minimize the possibility of oxidation have resulted in significantly higher observed concentrations for dissolved metals than did prior sampling techniques. These higher metal concentrations are compatable for saturation with phases such as iron carbonates and phosphates. The presence of vivianite in the sediment has already been shown (2) and is discussed above in connection with phosphate. Concentrations of trace metals in interstitial waters thus becomes a function not only of $\mathrm{pH}$ and Eh, but possibly of various metal-anion mineral equilibria. 
Spatial variation of iron is depicted in Figure 19. This station exhibits the poorest agreement among the cores of the

$\therefore$ : four stations sampled. The concentrations measured at $853-\mathrm{E}$

$\because 7$ agree to within about $\pm 10 \%$. Nevertheless, even at this station

$\therefore \dot{0}$ quantitative comparison of the cores is difficult, although

$\therefore$ : qualitatively, there is excellent agreement. The large varia-

$\therefore \quad$ tions observed are probably related to local equilibrium with

43 vivianite (compare the inverse relationship of Figures 15 and

$\therefore 2$ 19).

Soluble manganese distribution shown in Figure 20 for station 853-C also exhibits the largest variation among the four stations. Quantitatively, the data are probably good to about $\pm 25 \%$. The manganese distribulion is significantly different from iron, suggesting that its concentration is probably controlled by a different mechanism than that of iron. Holdren has suggested an equilibrium with rhodochrosite $\left(\mathrm{MnCO}_{3}\right)$, and gives a mathematical model for the manganese distribution in the next paper of this symposium (11).

\section{Conclusions}

Acquisition of a core from a given station is subject to two fundamental problems which affect the reliability of the data: 1) navigational accuracy which limits relocation of sample sites to $100^{\prime}-500^{\prime}$, and 2) variations in temperature, salinity, and sediment deposition rates on seasonal and on other time-scale cycles which can influence both the biological and inorganic processes taking place within the cores. Qualitatively, the reliability of spatial data is excellent for most chemical species studied. In general, spatial variations were only slightly greater than the limits set by the analytical techniques. Some important exceptions exist. Ground water infiltration can severely affect the interstitial water chernistry and may be an important influence in some areas of the bay. Also, the distribution of some chemical species is controlled by local mineral equilibria, and this decreases the reproducibility of spatial data. Temporal variations far exceed the limits of spatial variation for each chemical species investigated. For parameters which are conservative and/or influenced predominantly by inorganic activity, seasonal changes in salinity and temperature control the interstitial water profiles. Those species which are involved in the decomposition of organic matter also show a gross seasonal correlation, but other processes must be taking place. Additional work is needed to fully understand these temporal variations and their irnportance in governing the mass flux across the sediment-water interface. 


\section{Acknowledgements}

Most of the temporal data were collected by John Bray, Bruce Troup, Mini UhIfelder, and Virginia Cirant. The authors thank John Ferguson, David Given, Ruth Braun, and Betsy Daniel for their help in acquisition of the spatial data. Financial support was provided by AEC grant is the recipient of a Baltimore Gas and Electric Company Fellowship.

\section{Literature Cited}

1. Reeburgh, W. S, l.imnol. Occanugr. (1967) 12, 163-165.

2. Bray, J. T., Bricker, 0. P., and Troup, B. N., Science (1973) 180, 1362-1364.

3. Knudsen, M., "Hydrographic tables" 63 pp., G.E.C. Gad., Copenhagen, 1901.

4. Dollman, G. W., Environ. Sci. Technol. (1968) 2, 1027-1029.

5. Murphy, J. and Riley, J. P., Anal. Chim. Acta (1962) 27, 31-36.

6. Harwood, J. E., van Steenderen, R. A., and Kuhn, A. L., Water Res. (1969) 3, 417-423.

7. Bray, J. T., Ph.D. dissertation, 149 pp., The Johns Hopkins University, Baltimore, 1973.

8. Sandell, E. B., "Colorimetric determination of traces of metals" $1032 \mathrm{pp}$., Interscience, New York, 1959.

9. Solórzano, L.; Limnol. Oceanogr. (1969) 14, 799-801.

10. Strickland, J. D. H. and Parsons, T. R. "A practical handbook of seawater analysis", 311 pp., Bull. Fisheries Res. Board of Can. no. 167, 1968.

11. Holdren, G. R. Jr., Bricker, O. P. III, Elliott, A. J. and Matisoff, G. (this volume).

12. Mackenzie, F. T., Garrels, R. M., Bricker, O. P. and Bickley, F., Science (1967) 155, 1404-1405.

13. Hurd, D. C., Earth planet. Sci. Lett. (1972) 15, 411-417.

14. Lewin, J. C., Geochim. Cosmochim. Acta (1961) $\overline{21}, 182-198$.

15. Siever, R. and Hoodford, N., Geochim. Cosmochim. Acta (1973) 37, $1851-1880$.

16. Hurd, D. C., Geochim. Cosmochim. Acta (1973) 37, 2257-2282.

17. Fanning, K. A, and Pilson, M. E. Q., Science (1971) 17.3, $1228-1231$.

18. Reeburgh, W. S., Ph.D. dissertation, 94 pp., The Johns Hopkins University, Baltimore, 1967.

19. Richards, F. A., In "Chemical oceanography", vol. 1, J. P. Riley and G. Skirrow (eds.), 611-645, Academic, New York, 1965.

20. Hackenzie, F. T. and Garrels, R. M., Amer. Jour. Sci. (1966) 264, 507-252.

21. Berner, R. A., Scott, M. R. and Thomlinson, C., Limnol. Oceanogr. (1970) 15, 544-549. 
$\therefore$ :

4 Hopkins University, Baltimore, 1974.

43 23. Holdren, G. R. Jr., Ph.D. dissertation (in preparation),

$\therefore ; \quad$ The Johns Hopkins University, Baltimore.

24. Nissenbaum, A., Presley, B. J. and Kaplan, I. R., Geochim. 45 Cosmochim. Acta (1972) 36, 1007-1028.

43

42

41

$4 !$

39

30

37

Sent tiost mege 


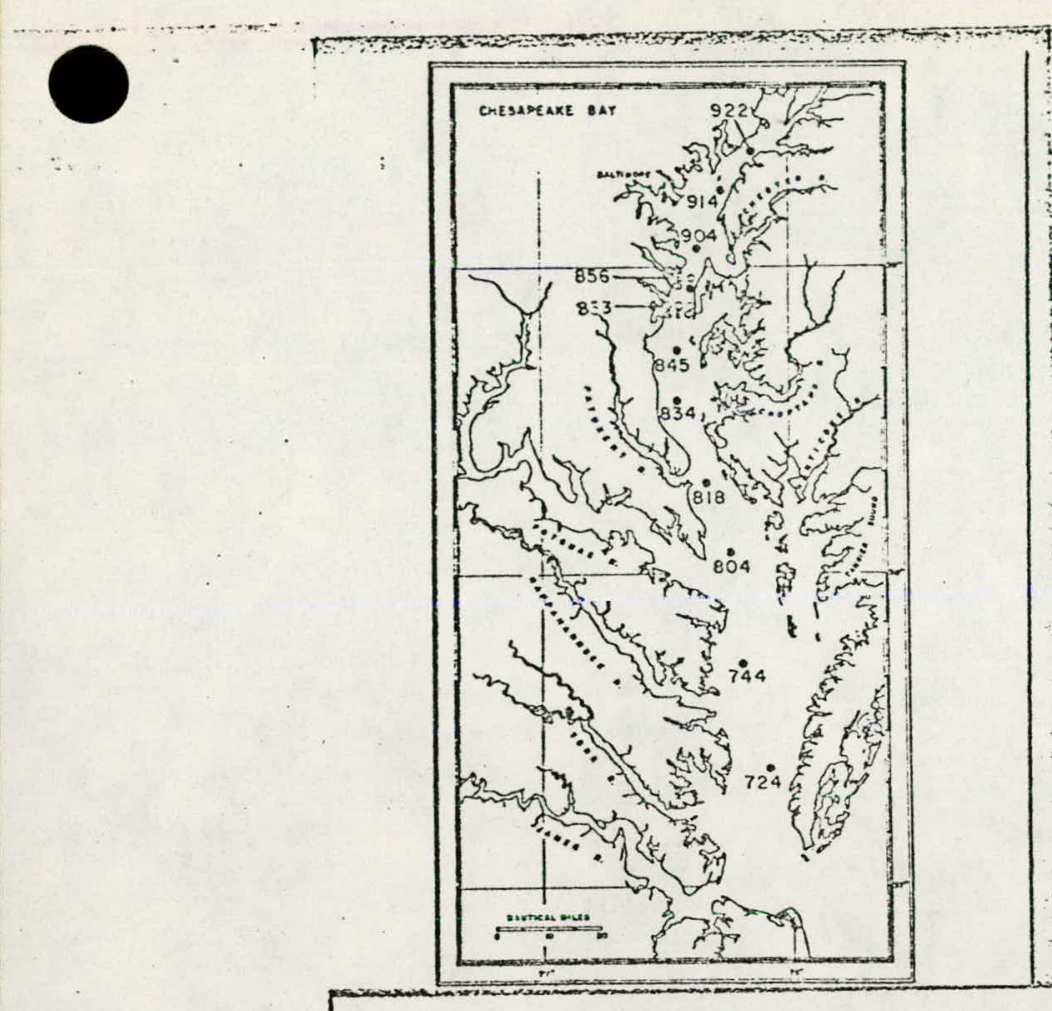

Fig. 1
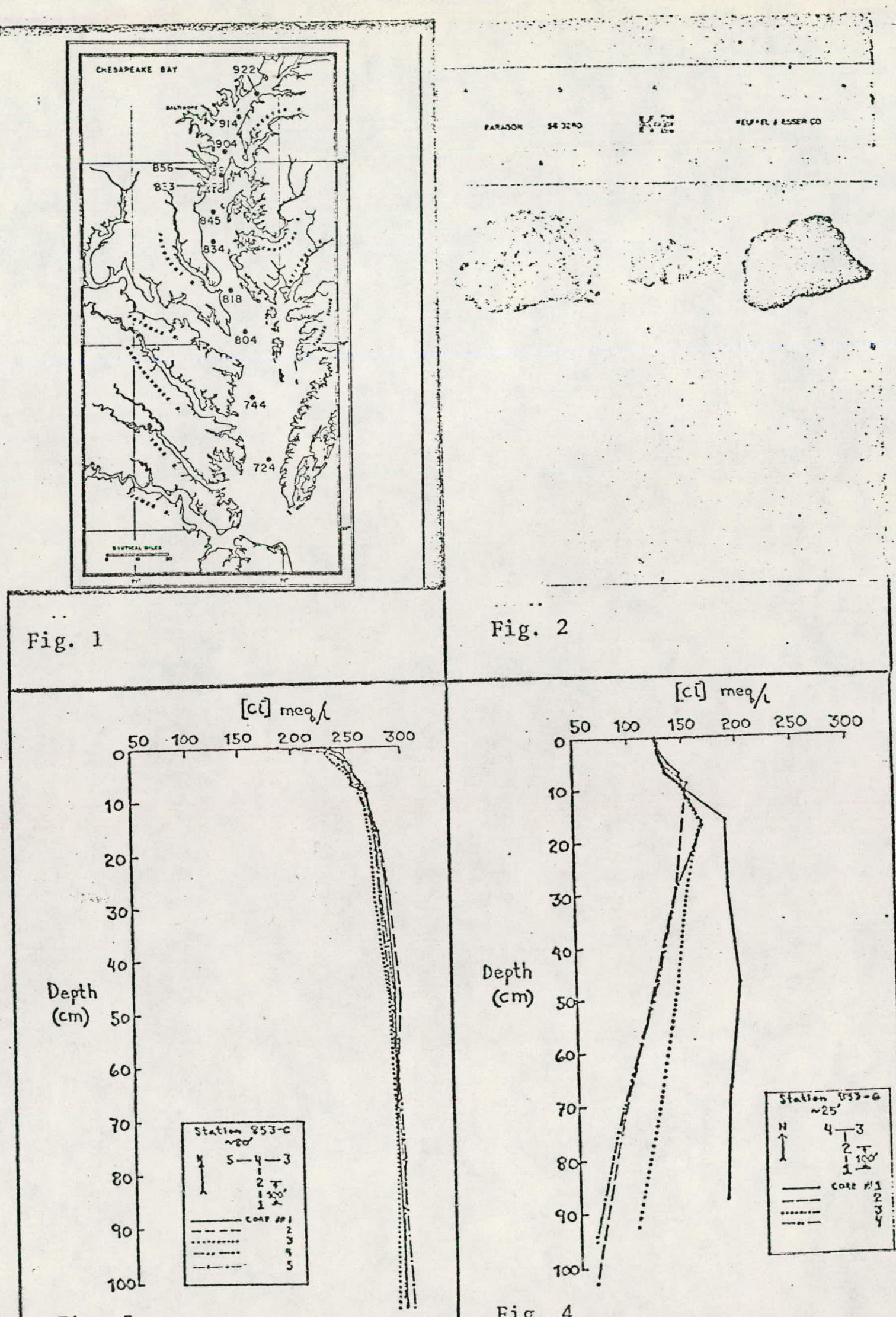

Fig. 3

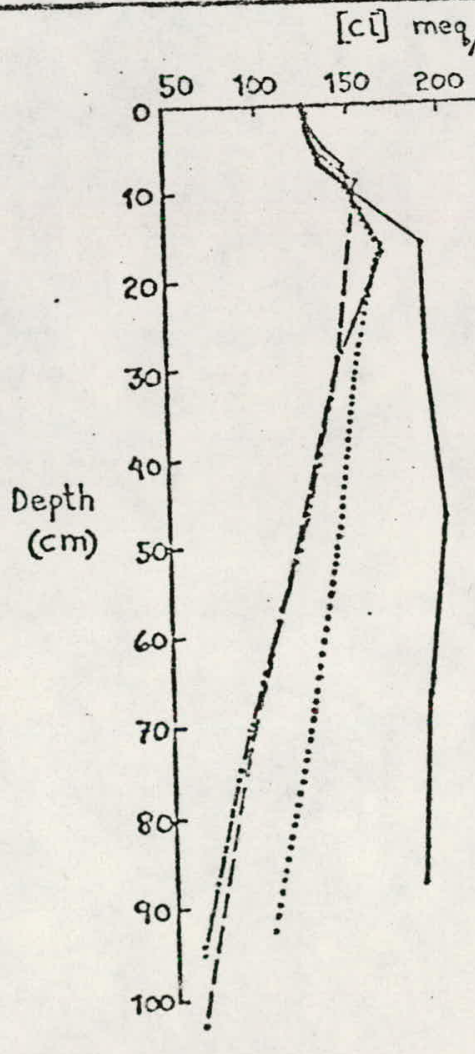

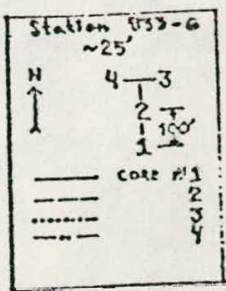

Fig. 4 


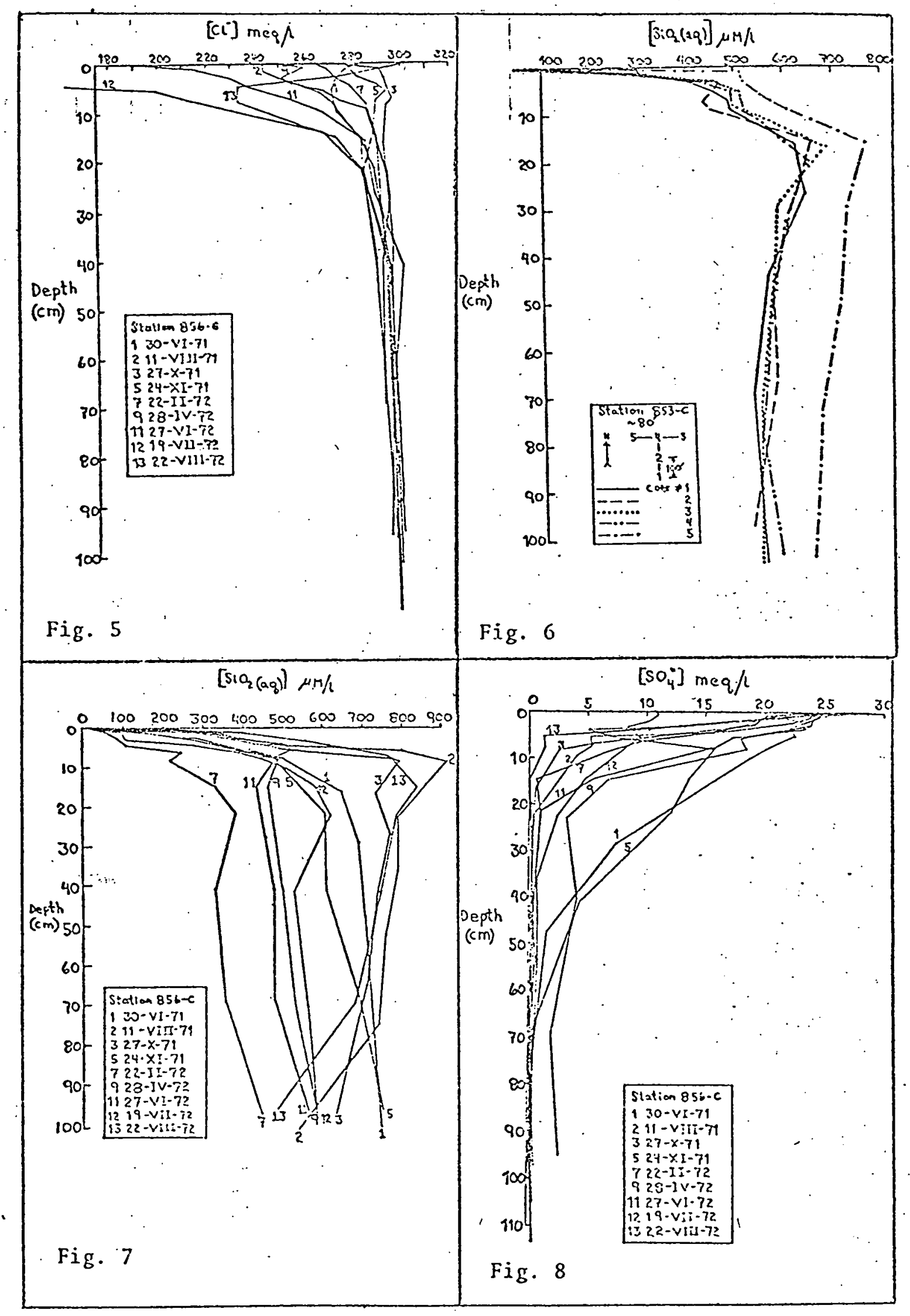




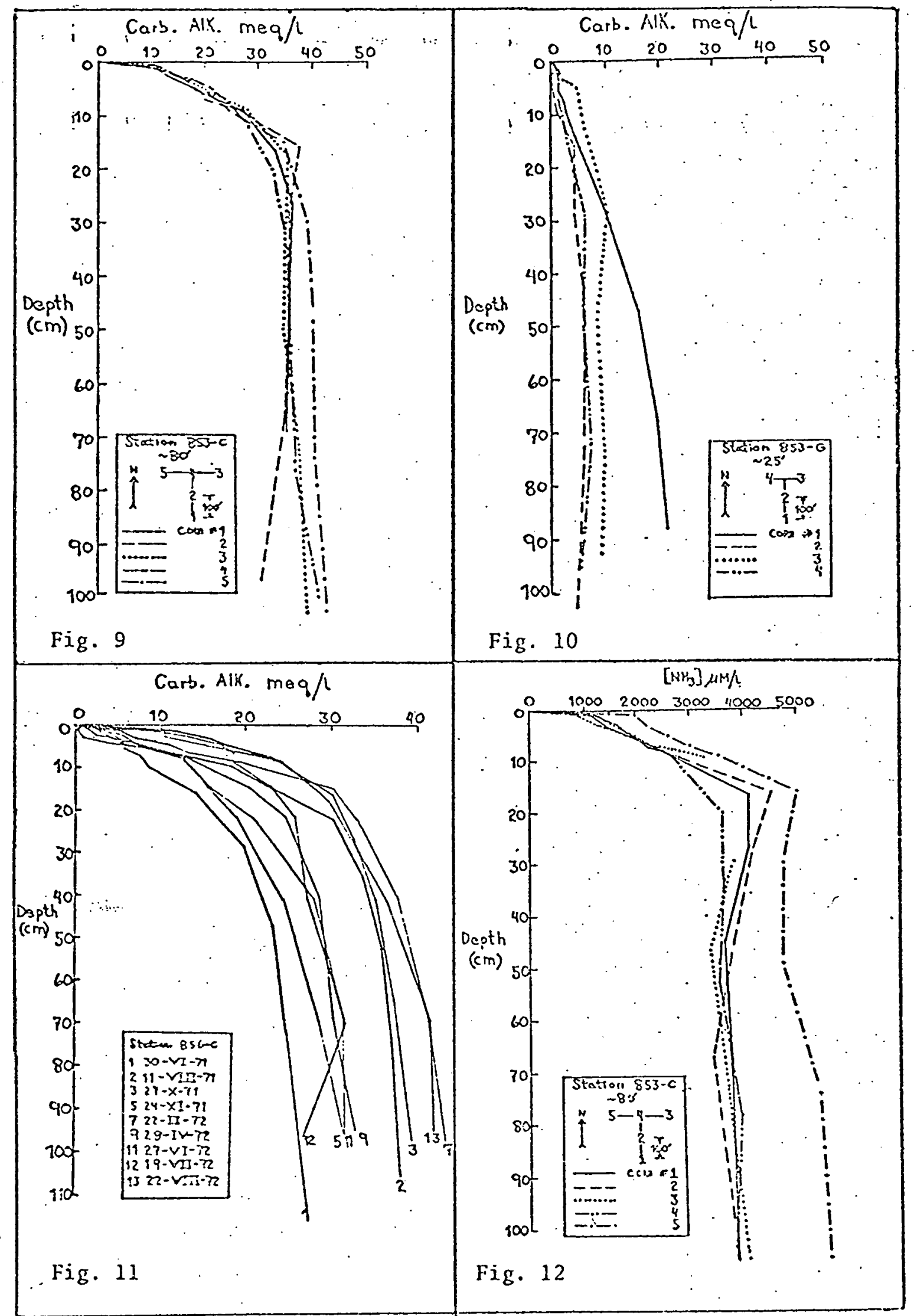




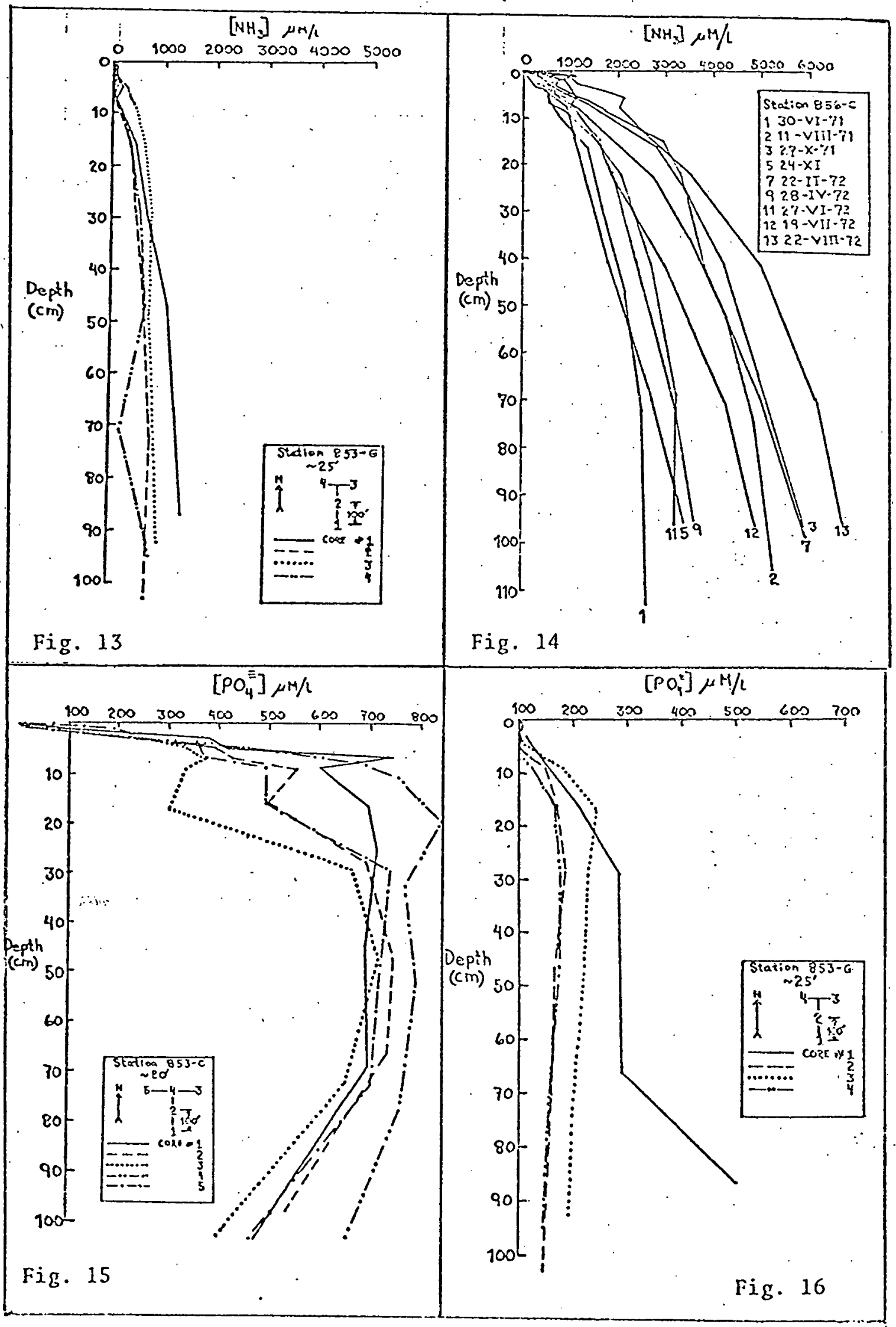

